\title{
Early detection of cancer in Nepal: Role of liquid biopsy
}

\author{
Sameer Chhetri Aryal ${ }^{1}$, Gopi Aryal ${ }^{2}$ \\ ${ }^{1}$ Department of Emergency Medicine, Alka Hospital Pvt. Ltd, Lalitpur, Nepal. \\ ${ }^{2}$ Department of Laboratory Medicine and Pathology, Nepal Mediciti Hospital Pvt. Ltd. Lalitpur, Nepal
}

\author{
Keywords: \\ Cancer; \\ Liquid biopsy; \\ Detection; \\ Nepal; \\ Circulating Tumor DNA; \\ Screening;
}

\begin{abstract}
Cancers of the uterine cervix, breast, lung and stomach are four of the most common cancers in Nepal. Lack of knowledge and awareness about cancer, its risk factors and negligence of the early warning signs play crucial role in raising the incidence of the cancer. Curative therapies are most successful when cancer is diagnosed and treated at an early stage.

Organized cancer screening programmes provide screening to target population and use multidisciplinary delivery teams, coordinated clinical oversight committees, and regular review by a multidisciplinary evaluation board. For population-based screening programs, decision- making and governance structures, tasks and procedures need to be defined.

In this paper, we review population-based cancer screening programmes of different countries and share recommendations and relevant evidence for screening and early detection of common cancers in Nepal. The evidence-based recommendations provided in this Review are intended to act as a guide for policy makers, clinicians, and public health practitioners who are developing and implementing strategies in cancer control. We also discuss the role of liquid biopsy in early detection, diagnosis and monitoring of cancers using circulating biomarkers. Despite challenges, time has come to include cell free circulating tumor DNA and circulating tumor cells, as a parameters for early detection of cancer in the days to come.
\end{abstract}

\section{Correspondence:}

Dr. Gopi Aryal, MD, PhD

Chair, Department of Laboratory Medicine and Pathology

Nepal Mediciti Hospital, Pvt. Ltd., Lalitpur, Nepal

ORCID ID: 0000-0002-8566-2593

E-mail: gopiaryal1@gmail.com

Reveived : June $11^{\text {th }} 2018$; Accepted : August $5^{\text {th }}$ 2018; Published : September $1^{\text {st }} 2018$

Citation: Chhetri SA, Aryal G. Early detection of cancer in Nepal: Role of liquid biopsy. J Pathol Nep 2018;8:1399-1407. DOI: 10.3126/jpn.v\%vi\%i.20893

Copyright: This is an open-access article distributed under the terms of the Creative Commons Attribution 4.0 International License, which permits unrestricted use, distribution, and reproduction in any medium, provided the original author and source are credited.

\section{INTRODUCTION}

Cancer is a molecular disease associated with alterations in the genome. Early diagnosis identifies symptomatic cancer cases at the earliest possible stage. Delays in cancer detection and late stage presentation are common problems in developing countries like Nepal. Even in countries with strong health systems and services, many cancer cases are diagnosed at a late-stage. The consequences of delayed or inaccessible cancer care are lower likelihood of survival, greater morbidity and higher costs of care.

Screening- seeks asymptomatic cancer or pre-cancerous lesions in a target population. There is no National cancerscreening program in Nepal till date. One of the most troubling misconceptions is the lack of belief people have in using routine diagnostic procedures to detect cancers while they are still in a manageable state. Many of these individuals believe that they are too young or that the screening tests are too expensive for serious consideration. 
Table 1: Sex wise prevalence of Cancer in Nepal.

\begin{tabular}{lccc}
\hline & Male & & Female \\
\hline Site & Frequency (\%) & Site & Frequency (\%) \\
\hline Lung & 19.08 & Cervix uteri & 21.9 \\
\hline Stomach & 7.86 & Breast & 15.6 \\
Larynx & 5.4 & Lung & 10.2 \\
Urinary Bladder & 4.18 & Ovary & 6.06 \\
Mouth & 3.94 & Hodgkin lymphoma & 5.43 \\
Melanoma of skin & 3.63 & Gallbladder & 4.57 \\
Hodgkin lymphoma & 3.36 & Stomach & 4.04 \\
Multiple myeloma & 3.24 & Thyroid & 2.46 \\
Esophagus & 3.16 & Melanoma of skin & 2.25 \\
Leukemia & 3.03 & Rectum and anus & 2.02
\end{tabular}

Over the ten-year period from 2003 to 2012, the top ten cancers in Nepal are given in Table $1 .^{1}$

\section{Predisposing factors for cancers:}

- Geographic and environmental factors

- $\quad$ Age (two extremes of age)

- Cancer with chromosomal aberrations

- Genetic predisposition

- $\quad$ Non-hereditary predisposing condition

\section{Carcinogens}

$\begin{array}{ll}\text { - } & \text { Chemical carcinogen } \\ \text { - } & \text { Radiation } \\ \text { Physical injury } \\ \text { Microbes } \\ \text { - Virus (oncogenic): } \\ \text { - RNA: HCV, HTLV-1 } \\ \text { DNA: HBV, human herpesvirus-8, } \\ \text { - Bacteria: H.pylori } \\ \text { - Parasites: S. hematobium, C. sinensis }\end{array}$

\section{MOLECULAR BASIS OF CANCER}

Development of all human cancer requires inherited germ line mutation or acquired mutation. Most important mutation involves proto-oncogenes, tumor suppressor gene and gene regulating apoptosis. DNA viruses such as papillomaviruses can promote the development of cancer by sequestering the products of tumor suppressor genes - in particular, the $\mathrm{Rb}$ protein, which regulates cell division, and the $\mathrm{p} 53$ protein, which is thought to act as an emergency brake on cell division in cells that have suffered genetic damage and to call a halt to cell division in senescent cells with shortened telomeres.

Cancer is the end-result of the accumulation of cell divisions in stem cells. However, cell division can lead to a variety of cancer-promoting errors, such as mutations and epigenetic mistakes occurring during DNA replication, chromosome aberrations arising during mitosis, errors in the distribution of cell-fate determinants between the daughter cells, and failures to restore physical interactions with other tissue components. As carcinogenesis progresses, the accumulation of DNA errors promotes cell division and eventually triggers cell division under permissive extracellular environments. The accumulation of cell divisions in stem cells drives not only the accumulation of the DNA alterations required for carcinogenesis, but also the formation and growth of the abnormal cell populations that characterize the disease. ${ }^{2}$

\section{CANCER SCREENING}

According to the recommendation by the Council of the European Union ${ }^{3}$, it is an ethical, legal and social prerequisite that cancer screening should only be offered to fully informed people with no symptoms if the screening is proved to decrease disease-specific mortality, if the benefits and risks are well known and if the cost-effectiveness of screening is acceptable.

The balance of benefits and harms is a strongly debated topic, particularly in the field of population-based cancer screening. The benefits from cancer screening are reduced cancer death, decreased chance of advanced disease at diagnosis and less expensive treatment. The harms include over-diagnosis, overtreatment, false-positive and false negative findings,

Each year, the American Cancer Society (ACS) publishes a summary of its guidelines for early cancer detection, data and trends in cancer screening rates from the National Health Interview Survey, and select issues related to cancer screening (Table 2). ${ }^{4}$

\section{LUNG CANCER SCREENING}

The ACS recommends annual screening for lung cancer with LDCT in adults aged 55 to 74 years in relatively good health who: 
Table 2: American Cancer Society Recommendations for the Early Detection of Cancer in Average-Risk Asymptomatic Adults.

\begin{tabular}{|c|c|c|c|}
\hline Cancer Site & Population & Test or Procedure & Recommendation \\
\hline \multirow[t]{2}{*}{ Breast } & $\begin{array}{l}\text { Women } \\
(40-45 \text { years })\end{array}$ & Mammography & $\begin{array}{l}\text { Women should undergo regular screening mammography starting at } \\
\text { age } 45 \mathrm{y} \text {; women aged } 45-54 \text { y should be screened annually; women } \\
\text { should have the opportunity to begin annual screening between the } \\
\text { ages of } 40 \text { and } 44 \text { years }\end{array}$ \\
\hline & $\begin{array}{l}\text { Women } \\
(\geq 55 \text { years })\end{array}$ & Mammography & $\begin{array}{l}\text { Women aged } \geq 55 \text { y should transition to biennial screening or have } \\
\text { the opportunity to continue screening annually; women should con- } \\
\text { tinue screening mammography as long as their overall health is good } \\
\text { and they have a life expectancy of } 10 \text { years or longer }\end{array}$ \\
\hline \multirow[t]{4}{*}{ Cervix } & $\begin{array}{l}\text { Women } \\
(21-29 \text { years })\end{array}$ & Pap test & $\begin{array}{l}\text { Cervical cancer screening should begin at age } 21 \text { years ; for women } \\
\text { aged 21-29 years, screening should be done every } 3 \text { years with } \\
\text { conventional or liquid-based Pap tests }\end{array}$ \\
\hline & $\begin{array}{l}\text { Women } \\
(30-65 \text { years })\end{array}$ & Pap test and HPV DNA test & $\begin{array}{l}\text { For women aged 30-65 years, screening should be done every } 5 \text { y } \\
\text { with both the HPV test and the Pap test (preferred), or every } 3 \text { years } \\
\text { with the Pap test alone (acceptable) }\end{array}$ \\
\hline & $\begin{array}{l}\text { Women } \\
(>65 \text { years })\end{array}$ & Pap test and HPV DNA test & $\begin{array}{c}\text { Women aged }>65 \text { y who have had } \geq 3 \text { consecutive negative Pap tests } \\
\text { or } \geq 2 \text { consecutive negative HPV and Pap tests within the last } 10 \\
\text { years, with the most recent test occurring in the last } 5 \text { years, should } \\
\text { stop cervical cancer screening }\end{array}$ \\
\hline & $\begin{array}{l}\text { Women who have } \\
\text { had a total hyster- } \\
\text { ectomy }\end{array}$ & Pap test and HPV DNA test & $\begin{array}{l}\text { Women who have had a total hysterectomy should stop cervical } \\
\text { cancer screening }\end{array}$ \\
\hline \multirow[t]{2}{*}{ Colorectal } & $\begin{array}{l}\text { Men and women, } \\
\text { aged } \geq 50 \text { years, } \\
\text { for all tests listed }\end{array}$ & $\begin{array}{l}\text { Fecal immunochemical test (FIT) } \\
\quad \text { [annual], or } \\
\text { High-sensitivity guaiac-based fe- } \\
\text { cal occult blood test (HSgFOBT) } \\
\quad \text { [annual], or } \\
\text { Multi target stool DNA test (mt- } \\
\text { sDNA), [every years per manu- } \\
\text { facturer's recommendation], or } \\
\text { Colonoscopy every10y], or } \\
\text { CT colonography (CTC) [every } \\
5 \text { years], or } \\
\text { Flexible sigmoidoscopy (FS) } \\
\text { [every } 5 \text { years] }\end{array}$ & $\begin{array}{l}\text { Adults aged } 45 \text { years and older should undergo regular screening } \\
\text { with either a high-sensitivity stool-based test or a structural (visual) } \\
\text { exam, depending on patient preference and test availability. As part } \\
\text { of the screening process, all positive results on non-colonoscopy } \\
\text { screening tests should be followed up with timely colonoscopy. } \\
\text { Adults in good health with a life expectancy of greater than } 10 \text { y } \\
\text { should continue screening through the age of } 75 \text { years . } \\
\text { Screening decisions should be individualized, based on patient pref- } \\
\text { erences, life expectancy, health status, and prior screening history. } \\
\text { If a decision is made to continue screening patient should be offered } \\
\text { options as listed above. }\end{array}$ \\
\hline & & & Individuals should be discouraged from continuing screening. \\
\hline Endometrial & $\begin{array}{l}\text { Women, at meno- } \\
\text { pause }\end{array}$ & Stomach & $\begin{array}{l}\text { At the time of menopause, women should be informed about risks } \\
\text { and symptoms of endometrial cancer and strongly encouraged to } \\
\text { report any unexpected bleeding or spotting to their physicians }\end{array}$ \\
\hline Lung & $\begin{array}{l}\text { Current or former } \\
\text { smokers ( } 55-74 \\
\text { years ) in good } \\
\text { health with at least } \\
\text { a } 30 \text { pack/year }\end{array}$ & Low-dose helical CT & $\begin{array}{l}\text { Annual screening in adults who: } 1 \text { currently smoke or have quit } \\
\text { within the past } 15 \text { years; and } 1 \text { have at least a } 30 \text { pack-year smoking } \\
\text { history; and } 1 \text { receive evidence- based smoking cessation counseling, } \\
\text { if they are current smokers; and } 1 \text { have undergone a process of in- } \\
\text { formed/shared decision making that included in formation about the } \\
\text { potential benefits, limitations, and harms of screening with low-dose } \\
\text { CT; and } 1 \text { have access to a high-volume, high quality lung cancer } \\
\text { screening and treatment center. }\end{array}$ \\
\hline Prostate & Men $\geq 50$ years & $\begin{array}{l}\text { Prostate specific antigen test } \\
\text { (PSA) with or without digital } \\
\text { rectal examination (DRE) }\end{array}$ & $\begin{array}{l}\text { Men who have at least a } 10 \text {-years life expectancy should have an } \\
\text { opportunity to make an informed decision with their health care pro- } \\
\text { vider about whether to be screened for prostate cancer after receiving } \\
\text { information about the potential benefits, risks, and uncertainties } \\
\text { associated with prostate cancer screening; prostate cancer screening } \\
\text { should not occur without an informed decision-making process }\end{array}$ \\
\hline
\end{tabular}

* Abbreviations: CT, computed tomography; HPV, human papillomavirus; MRI, magnetic resonance imaging; Pap, Papanicolaou

* All individuals should become familiar with the potential benefits, limitations, and harms associated with cancer screening.

- $\quad$ Currently smoke or have quit within the past 15 years; and

- Have at least a 30-pack-year smoking history; and
- $\quad$ Receive evidence-based smoking-cessation counseling, if they are current smokers; and

- Have undergone a process of informed/shared decision making that included information about the potential 


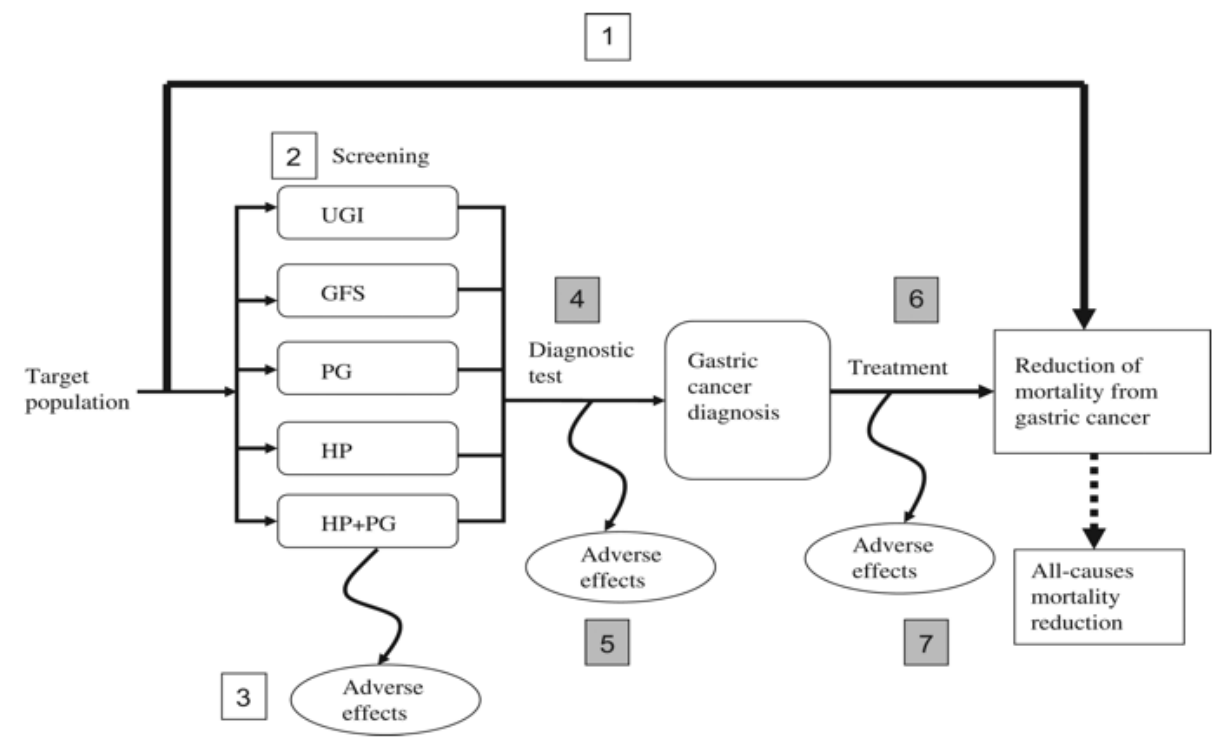

Figure 1: Analytic framework and key questions for gastric cancer screening. 1. Is there direct evidence that the mortality from gastric cancer is reduced with the following screening methods? (a) Upper gastrointestinal series (UGI), (b) gastrointestinal endoscopy (GFS), (c) serum pepsinogen test (PG) Helicobacter pylori antibody (HP), (d) Helicobacter pylori antibody (HP), (e) A combined method of Helicobacter pylori antibody and serum pepsinogen test (HP $+P G)$. 2. Can the screening test accurately detect gastric cancer? What are the sensitivity and specificity of the screening test? 3. What are the potential harms of the screening tests, and how often do they occur? 4. Can the diagnostic test accurately diagnose gastric cancers? 5. What are the potential harms of the diagnostic examination, and how often do they occur? 6. For gastric cancer patients, how are the efficacy and effectiveness of the treatment? 7. What are the potential harms of gastric cancers treatment, and how often do they occur?

benefits, limitations, and harms of screening with LDCT and

- Have access to a high-volume, high-quality lung cancer screening and treatment center.

\section{GASTRIC CANCER SCREENING}

The following methods were assessed for gastric cancer screening:

I. Upper gastrointestinal series (radiographic screening)

II. Gastrointestinal endoscopy (endoscopic screening)

III. Helicobacter pylori antibody test and serum pepsinogen tests

Analytic framework for gastric cancer screening is shown in figure $1 .^{5}$

\section{SCREENING FOR BREAST CANCER}

The ACS recommends that women aged 45 to 54 years and those aged 40 to 44 years who choose to begin screening before age 45 , should be screened annually, and women aged 55 years and older should transition to biennial screening or can continue annual screening if that is their preference.

\section{SCREENING WOMEN AT HIGH RISK}

Annual screening mammography and magnetic resonance imaging (MRI) starting at age 30 years are recommended for women with a known BRCA mutation, women who are untested but have a first-degree relative with a BRCA mutation, or women with an approximately $20 \%$ to $25 \%$ or greater lifetime risk of breast cancer based upon specialized breast cancer risk-estimation models capable of pedigree analysis of first-degree and second-degree relatives on both the maternal and paternal sides. Annual MRI and mammography also are recommended for women who were treated for Hodgkin disease with radiation to the chest between ages 10 and 30 years and women with Li-Fraumeni, Cowden, and Bannayan-Riley-Ruvalcaba syndromes. Analytical framework for breast cancer is shown in figure $2 .{ }^{6}$

\section{SCREENING FOR CERVICAL CANCER}

\section{Special Considerations}

These recommendations are intended for women at average risk and do not apply to women with a history of cervical cancer; women who were exposed in utero to diethylstilbestrol; women who are immunocompromised by organ transplantation, chemotherapy, or chronic 


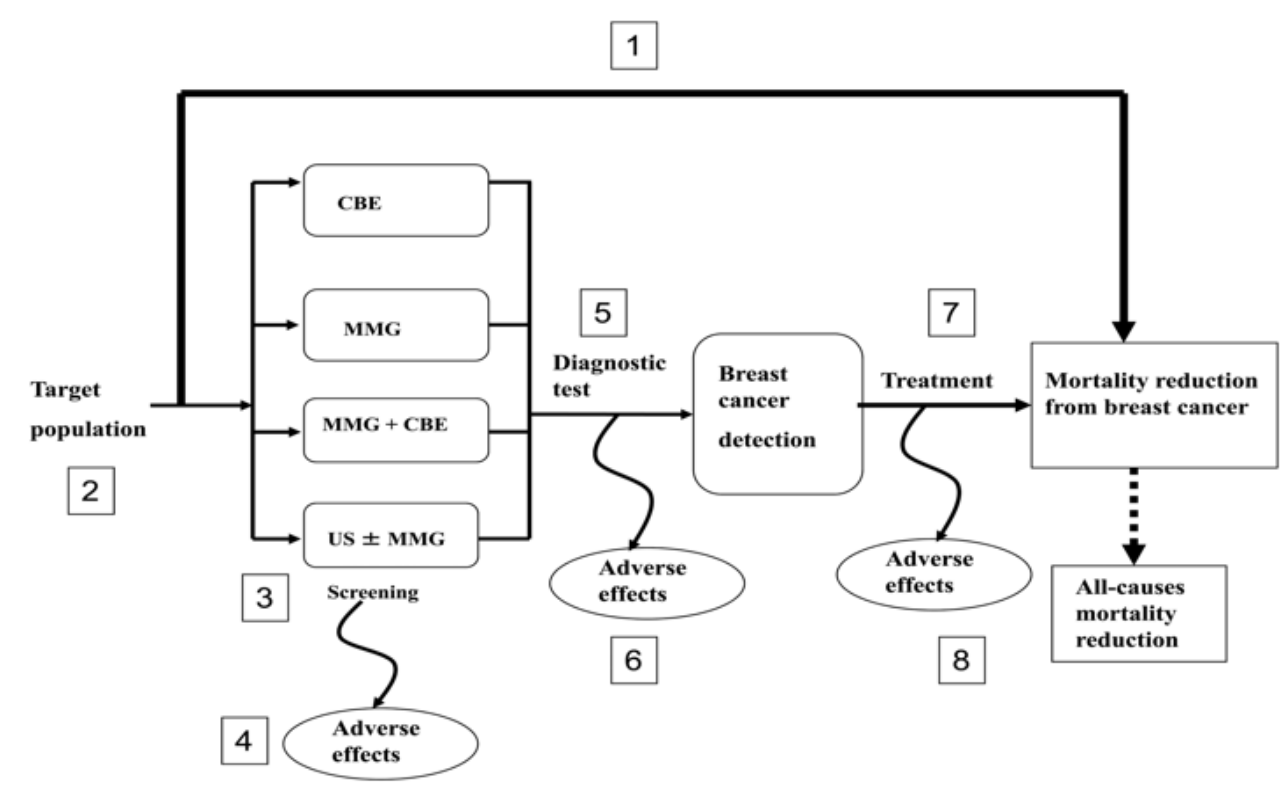

Figure 2: (1) Compared with no screening (or other screening strategies), is there direct evidence that the mortality from breast cancer is reduced with the following screening methods? (a) Clinical breast examination (CBE). (b) Mammography $(M M G)$. (c) Mammography with clinical breast examination $(M M G+C B E)$. (d) Ultrasonography with and without mammography (US $\pm M M G$ ). To appropriately determinate the level of evidence, the primary outcomes of mortality from breast cancer must be ascertained. (2) What age group was the preferable target for breast cancer screening? (3) Can the screening test accurately detect breast cancer? What are the sensitivity and specificity rates of the screening test? (4) What are the potential harms of screening tests, and how often do they occur? (5) Can the diagnostic test accurately detect the target women? (6) What are the potential harms of diagnostic tests, and how often do they occur? 7) (For breast cancer patients, how are the efficacy and effectiveness of treatment?

corticosteroid treatment; or women who are positive for the human immunodeficiency virus. In addition, women who have had their cervix removed should not be screened unless they have a history of CIN2 or a more severe diagnosis. Women who have undergone a subtotal (supracervical) hysterectomy should be screened following the recommendations for average-risk women who have not undergone a hysterectomy.

\section{Vaccination Against HPV}

The ACS recommends vaccination of all children at ages 11 and 12 years to protect against HPV infections that lead to several cancers and pre-cancers. The vaccination series can be started beginning at age 9 years.

Cervical cancer screening using conventional and liquidbased cytology is recommended for population-based and opportunistic screening due to sufficient evidence. Cervical cancer screening using either human papillomavirus testing alone or two combination methods is not recommended for population-based screening due to insufficient evidence. Analytical framework is shown in figure $3 .^{7}$

\section{SCREENING OF COLORECTAL CARCINOMA}

Specidally high-risk adults to colorectcal carcinoma (CRC) should undergo routine screening program. Higher risk for CRC include:

1. Individuals with a history of adenomatous polyps

2. Individuals with a personal history of curative $\square$ intent resection of CRC

3. Individuals with a family history of either CRC or colorectal adenomas diagnosed in a first degree relative, with differing recommendations based on the relative's age at diagnosis;

4. Individuals with a history of inflammatory bowel disease of significant duration;

5. Individuals with a known or suspected presence of 1 of 2 hereditary syndromes, specifically, Lynch syndrome (hereditary nonpolyposis colon cancer) or familial adenomatous polyposis; or 6) individuals with a history of abdominal or pelvic radiation for a previous cancer. For these individuals, increased surveillance generally means a specific recommendation for colonoscopy if available and may include more frequent examinations and examinations beginning at an earlier age.

\section{ROLE OF LIQUID BIOPSY}




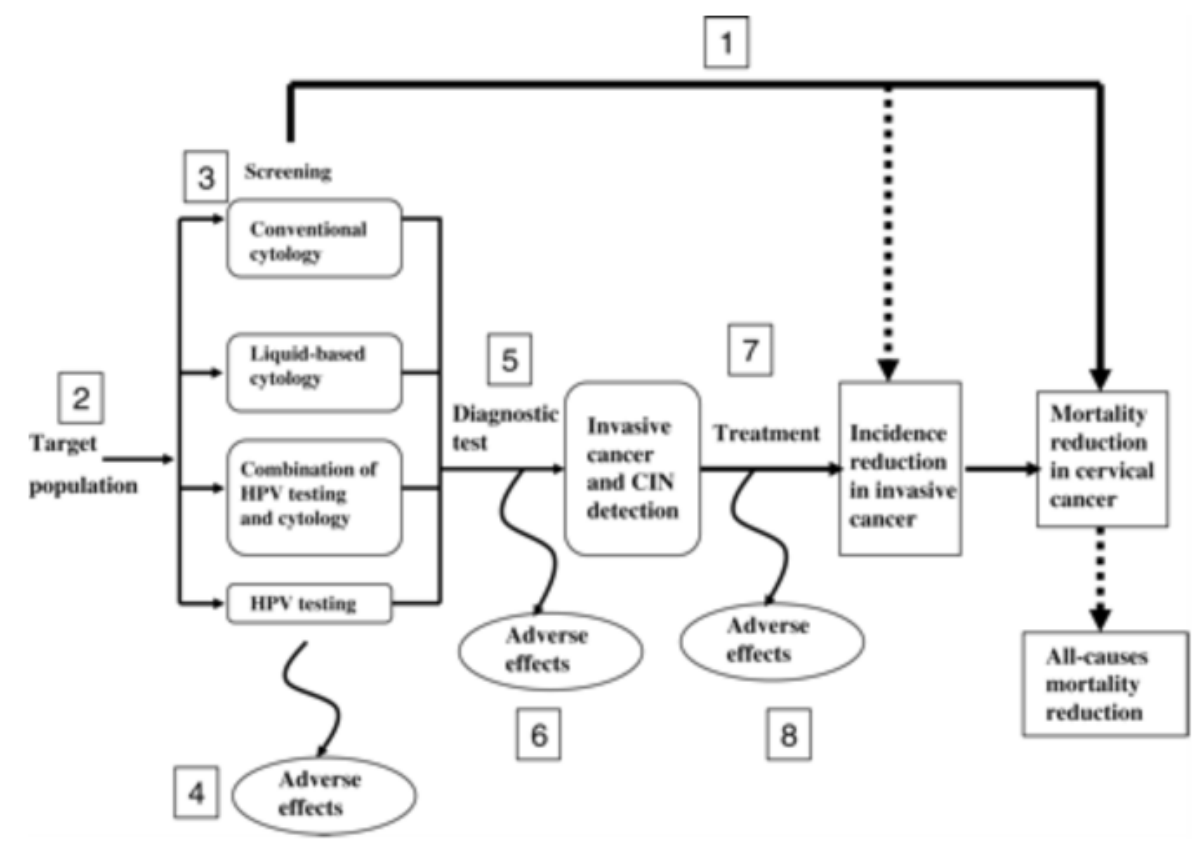

Figure 3: (1) is there direct evidence that following screening, the incidence and/or mortality are reduced? (2) Is the prevalence of cervical cancer in the target group? What strategy can reliably identify a high-risk group from among averagerisk persons? (3) Can the screening test accurately detect the target cancer? The screening methods are conventional cytology, liquid-based cytology, combination of HPV testing and cytology and HPV testing alone. (4) Does screening result in adverse effects compared to no screening? (5) Can the diagnostic test accurately detect the target cancer? The diagnostic method is LEEP (loop electrosurgical excision procedure). (6) Does the diagnostic test result in adverse effects compared to no test? (7) For cervical cancer patients, does any treatment reduce the incidence of an intermediate outcome compared to no treatment (or other treatment)? (8) Does any treatment result in adverse effects?

A liquid biopsy is an analysis of liquid biomarkers that can be isolated from body fluids (urine, feces, saliva, sputum, pleural fluid, and cerebrospinal fluid) and blood. Liquid biopsies, mainly represented by circulating tumor cells, circulating tumor DNA, tumor exosomes, and microRNAs, have the potential to assess various biomarkers for early detection of cancer, monitoring tumor progression along with prognosis.

Biomarkers that are currently in use or under investigation in liquid biopsies are also shown in the Table $3 .^{8}$
CT, computed tomography; MRI, magnetic resonance imaging; PET, positron emission tomography; CA-125, carcinoma antigen-125; CEA, carcinoembryonic antigen; PSA, prostate-specific antigen; CTC, circulating tumor cell; ctDNA, circulating tumor DNA; cfRNA, cell-free RNA.

Currently, there is no pancreatic cancer-screening program. Most commonly used blood-based tumor biomarkers in clinical practice are carbohydrate antigen (CA) 19-9 and carcinoembryonic antigen (CEA). Peripheral venous blood is collected from the patients for isolation of circulating tumor cells (CTCs), circulating tumor DNA (ctDNA) and

Table 3. Comparison of different cancer detection methods and their clinical utilities

\begin{tabular}{|c|c|c|c|}
\hline \multicolumn{2}{|r|}{ Detection method } & Strengths & Limitations \\
\hline \multicolumn{2}{|r|}{$\begin{array}{l}\text { Imaging-based methods } \\
\text { (CT, MRI, PET, etc.) }\end{array}$} & $\begin{array}{c}\text { Rapid; easy to use; displaying solid tumor } \\
\text { visually }\end{array}$ & $\begin{array}{l}\text { Unable to detect minimal residual disease; exposing } \\
\text { patients to additional ionizing radiation }\end{array}$ \\
\hline \multicolumn{2}{|r|}{ Solid biopsy } & $\begin{array}{l}\text { Reflecting certain histological issues; short } \\
\text { operating time }\end{array}$ & $\begin{array}{l}\text { Unable to represent the entre tumor due to the intra- } \\
\text { and inter-tumor heterogeneity; serial biopsy often } \\
\text { impractical; discomfort suffered by the patient; not } \\
\text { accessible for some tumors }\end{array}$ \\
\hline \multirow[t]{2}{*}{$\begin{array}{l}\text { Liquid } \\
\text { biopsy }\end{array}$} & $\begin{array}{c}\text { Protein (CA-125, CEA, } \\
\text { PSA, etc.) }\end{array}$ & Non-invasive; easy to obtain & $\begin{array}{l}\text { Low specificity; Unable to be detected in vast major- } \\
\text { ity of patients with advanced cancers }\end{array}$ \\
\hline & CTCs & $\begin{array}{c}\text { Non-invasive; high specificity; demonstrating } \\
\text { colocalization of signals; evaluating protein } \\
\text { expression; potentially addressing tumor } \\
\text { heterogeneity }\end{array}$ & $\begin{array}{l}\text { Low signal-to-noise; affected by heterogeneity on } \\
\text { selection methods }\end{array}$ \\
\hline
\end{tabular}


Table 3. Comparison of different cancer detection methods and their clinical utilities ( continued )

$\begin{array}{ccc}\text { Detection method } & \text { Strengths } \\ \text { Limitations } & \begin{array}{c}\text { Non-invasive; high specificity; demonstrating } \\ \text { colocalization of signals; evaluating protein } \\ \text { expression; potentially addressing tumor } \\ \text { heterogeneity }\end{array} \\ \text { CtDNA } & \begin{array}{c}\text { Non-invasive; high specificity and sensitivity; } \\ \text { providing personalized snapshot of disease; } \\ \text { fully representing tumors }\end{array} & \begin{array}{c}\text { Low signal-to-noise; lack of co-localization, protein } \\ \text { expression, and functional studies }\end{array} \\ \text { Circulating cfRNA } & \begin{array}{c}\text { Non-invasive; stable; demonstrating distinct } \\ \text { gene expression patterns from particular } \\ \text { tumor }\end{array} & \begin{array}{c}\text { Lack of large-scale studies; lack of correlations } \\ \text { between tumor behavior and findings }\end{array} \\ \text { Non-invasive; stable within exosomes; easy } \\ \text { to isolate or enrich }\end{array}$

exosomes. These circulating biomarkers are applied to guide initial diagnosis and treatment monitoring for patients with pancreatic cancer. ${ }^{9}$

Tumor-educated blood platelets (TEP) are involved in the progression and spread of several solid tumors, and spliced TEP RNA surrogate signatures can provide specific information on the presence, location, and molecular characteristics of cancers. TEP samples from patients with lung, brain, and breast cancers, have been tested, and it has been shown that TEPs from patients with cancer are distinct from those with inflammatory and other noncancerous diseases. Ultimately, TEP RNA may complement currently used biomolecules employed for liquid biopsy diagnosis, potentially enhancing the detection of cancer in an early stage and facilitating noninvasive disease monitoring. ${ }^{10}$

Emerging evidence has demonstrated the feasibility of circulating miRNAs as robust non-invasive biomarkers for the diagnosis in colorectal cancer. The use of circulating miRNAs for the early detection of colorectal cancer (CRC) is of particular interest as it can offer a potential complementary approach to screening colonoscopy. ${ }^{10}$

Cell free circulating tumor DNA (ctDNA), circulating tumor cells (CTCs), exosomes and tumor-educated platelets (TEPs), have also been widely investigated for their potential role in lung cancer diagnosis. ${ }^{11}$

Quantitative real-time polymerase chain reaction data showed circulating miRNA-22-3p had significantly different expression in patients with precancerous lesions or gastric adenocarcinoma. ${ }^{12}$

Current available imaging modalities do not reveal micrometastasis and tumor biopsy is an invasive method to detect early stage or recurrent cancer, signifying the need for an inexpensive, non-invasive diagnostic modality. Current evidence suggests that increasing levels of ctDNA in breast cancer can be of significant diagnostic value for early detection of breast cancer. ${ }^{13}$

Urinary cfNA holds potential for a more sensitive alternative to blood biopsies and urine sediment-based tests for clinical use in GU cancers. ${ }^{14}$

\section{DISCUSSION}

Lack of knowledge and awareness about cancer, its risk factors and negligence of the early warning signs play crucial role in raising the incidence of the disease. Awareness programs through newspapers, radio, television and health campaigns regarding the early signs of cancer and benefit of detection at early stage are important factors to reduce cancer mortality. Three is significant challenges for Cancer Screening. For instance, high false-positive rates from mammography in breast cancer screening, low- dose CT in lung cancer screening, and prostate-specific antigen (PSA) screening represent a significant cost to the healthcare system, with resulting mental and physical morbidity.

\section{Early signs of cancer}

- Lumps

- Sores that fail to heal

- Abnormal bleeding, post coital bleeding

- White lesion in oral cavity

- Persistent Hoarseness of voice

- Changes to moles or warts

- Persistent fatigue, weakness

- Unexplained weight loss, change in bowel habit, anemia

- White spot in pupil

- Enlarged lymph node, liver or spleen

- Easy bleeding or bruising, bone pain or tenderness

In Nepal, the major cancers in males are lung cancer followed by stomach cancer. Among females, the three common cancers are cervix followed by breast and lung. ${ }^{1}$

The increase incidence of cancer is largely attributable to a multitude of factors including an ageing population, increased life expectancy, a high prevalence of modifiable risk factors, poorly integrated primary and secondary prevention programmes, and inefficient or inaccessible treatment delivery systems. ${ }^{15}$ 


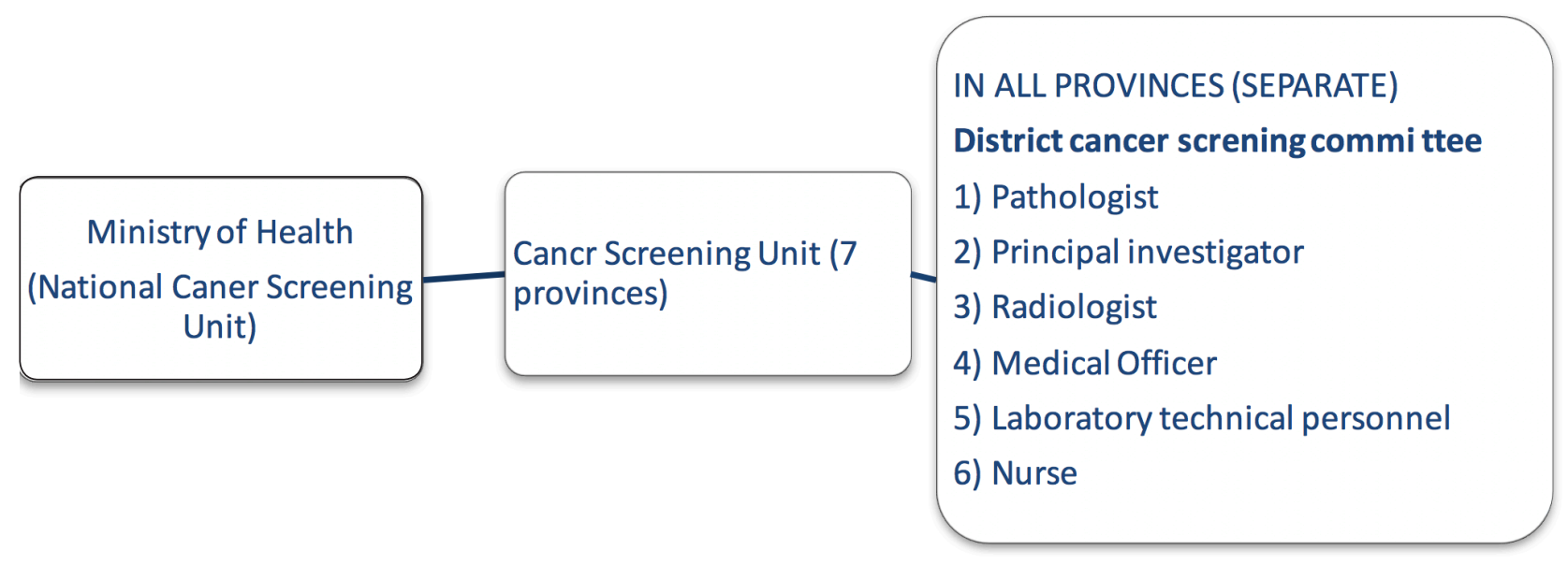

Figure 4: Proposed organogram for cancer screening program in Nepal.

In 2017, WHO member states adopted the draft resolution, which underscores cancer control as a national public health priority, with specific emphasis on screening and assessment of screening programmes. ${ }^{16}$

Following are the six essential elements of national cancer screening programs:

\section{Policy elements}

- Area to be covered by screening activity

- Age group

- Recruitment method

- Screening method

- Screening provider

- Financing and insurance systems

- Screening interval

- Method for follow-up of abnormal findings

- Follow-up provider

- Payment for follow-up or treatment

- Data files to follow up individuals targeted by screening or alternative documentation methods

- Performance indicators

- Time interval for publication of performance indicators

- Quality indicators, process indicators, and access to diagnosis

- Access to treatment

- Trained human resources and facility infrastructure for screening

2. Recognition of the fact that screening is a process and not simply a discrete event. ${ }^{17}$

3. Development of a strong infrastructure for screening implementation

\section{Establishment of Monitoring and assessment system}

\section{Planning for community engagement}

\section{Implementation science research}

There is no national or provincial cancer-screening program in Nepal. As a country with limited resources, Nepalese government need to start population based cancer-screening program at least for cancer of lung, stomach, cervix, breast and bowel. We have proposed organogram of cancer screening program in Nepal (fig. 4).

The advent of therapies targeting genomic alterations has improved the care of patients with certain types of cancer. While molecular targets were initially detected in nucleic acid samples extracted from tumor tissue, detection of nucleic acids in circulating blood has allowed the development of what has become known as liquid biopsies.

The attitude of pathologists to and level of involvement in the practice of liquid biopsies, including mastering the methods employed in molecular analysis of blood samples, need close attention. Regardless of the level of involvement of pathologists in this new field, it is mandatory that oncologists, radiologist and pathologists work together to coordinate the pre-analytical, analytical, and post-analytical phases of molecular assessment of tissue and liquid samples of individual cancer patients.

\section{The challenges include:}

(1) Implementation of effective and efficient procedures for reception and analysis of liquid and tissue samples for histopathological and molecular evaluation and

(2) Assuring short turn-around times (TAT) to facilitate rapid optimization of individual patient treatment. ${ }^{18}$

\section{CONCLUSION}

Regardless of income levels, countries around the world are identifying approaches to offer cancer-screening 
programmes to their residents via financing, community engagement, and strengthening of health-care systems. By recognizing that screening is a step in the continuum of cancer care, governments can use available technologies and human resources to help detect cancers early and treat them successfully.

Early detection of cancer and screening programmes across Nepal including a well-developed analytical framework need to develop. Periodic follow-up and quality assurance is essential for the same. Despite challenges, time has come to include cell free circulating tumor DNA (ctDNA) and circulating tumor cells (CTCs), as a parameters for early detection of cancer in the days to come.

\section{Conflict of Interest: None}

\section{REFERENCES}

1. Poudel KK, Huang Z, Neupane PR, Steel R, Poudel JK. HospitalBased Cancer Incidence in Nepal from 2010 to 2013. Nepal J Epidemiol. 2017;31:659-65. Crossref

2. López-Lázaro M. The stem cell division theory of cancer. Crit Rev Oncol Hematol. 2018;123:95-113. Crossref

3. Council of the European Union. Council recommendation of 2 December 2003 on cancer screening (2003/878/EC). OJ, 2003;327:34-8.

4. Smith RA, Andrews KS, Brooks D, et al. Cancer screening in the United States, 2018: A review of current American Cancer Society guidelines and current issues in cancer screening. CA Cancer J Clin. $2018 ; 10.3322 /$ caac.21446. Crossref

5. Hamashima C. Update version of the Japanese Guidelines for Gastric Cancer Screening. Jpn J Clin Oncol. 2018;48:673-83. Crossref

6. Hamashima C, Hattori M, Honjo S et al. The Japanese Guidelines for Breast Cancer Screening. Jpn J Clin Oncol. 2016;46:482-92. Crossref
7. Chisato Hamashima, Daisuke Aoki, Etsuko Miyagi et al. The Japanese Guideline for Cervical Cancer Screening. Jpn J Clin Oncol 2010;40:485-502. Crossref

8. Han X, Wang J, Sun Y. Circulating Tumor DNA as Biomarkers for Cancer Detection. Genomics Proteomics Bioinformatics. 2017;15:59-72. Crossref

9. Yadav DK, Bai X, Yadav RK, et al. Liquid biopsy in pancreatic cancer: the beginning of a new era. Oncotarget. 2018;9:26900-33. Crossref

10. Chisato H, Daisuke A, Etsuko M, et al.. The Japanese Guideline for Cervical Cancer Screening. Jpn J Clin Oncol 2010;40:485-502. $\underline{\text { Crossref }}$

11. Santarpia M, Liguori A, D'Aveni A et al. Liquid biopsy for lung cancer early detection. J Thorac Dis. 2018;10:S882-S897. Crossref

12. Chen TH, Chiu CT, Lee $\mathrm{C}$ et al. Circulating microRNA-22-3p Predicts the Malignant Progression of Precancerous Gastric Lesions from Intestinal Metaplasia to Early Adenocarcinoma. Dig Dis Sci. $2018 ; 10.1007 /$ s10620-018-5106-4. Crossref

13. Rohanizadegan M. Analysis of circulating tumor DNA in breast cancer as a diagnostic and prognostic biomarker. Cancer Genet. 2018;:S2210-7762:30292-2.

14. Lin SY, Linehan JA, Wilson TG et al. Emerging Utility of Urinary Cell-free Nucleic Acid Biomarkers for Prostate, Bladder, and Renal Cancers. Eur Urol Focus. 2017;3:265-72. Crossref

15. Farmer, P, Frenk, J, Knaul, FM et al. Expansion of cancer care and control in countries of low and middle income: a call to action. Lancet. 2010;376:1186-93. $\underline{\text { Crossref }}$

16. WHO. Cancer prevention and control in the context of an integrated approach: draft resolution proposed by Brazil, Canada, Colombia, Costa Rica, France, Netherlands, Nigeria, Panama, Peru, Russian Federation, Thailand and Zambia. ((accessed June 2, 2018). Crossref

17. Taplin, $\mathrm{SH}$, Anhang Price, R, Edwards, HM et al. Introduction: understanding and influencing multilevel factors across the cancer care continuum. J Natl Cancer Inst Monogr. 2012;2012:2-10. $\underline{\text { Crossref }}$

18. Hofman P, Popper HH. Pathologists and liquid biopsies: to be or not to be? Virchows Arch. 2016;469:601-9. Crossref 